\title{
The Analysis of Unreasonable Transportation in Modern Logistics and Related Measures
}

\author{
Wang Qingjun \\ School of Economic and Management \\ Shengyang Aerospace University \\ Shengyang China \\ 32582669@qq.com
}

\author{
Li Yaofei \\ School of Economic and Management \\ Shengyang Aerospace University \\ Shengyang China \\ 362836435@qq.com
}

\begin{abstract}
Modern logistics has become an integral part of modern society an important part of the economic development of modern society, it has an important significance. Transportation is a very important part of the logistics of each part of the problem is unreasonable transportation logistics and transport in a focus issue, but also in our physical logistics operations often met the problem. Logistics and transportation sector is a pillar of social and economic development sectors, due to China's logistics and transportation sector in the initial stage of development, there are still many problems to be solved, compared with foreign logistics, China's logistics and transportation sector lagged behind. For the development of logistics and transportation sector in our country, we must first logistics and transport situation in our country there is a profound understanding, analyze and solve its problems, in order to strengthen our management and transport logistics and transportation sector level..Unreasonable transportation logistics enterprises in the current capacity can be achieved under the transport, but did not reach the level of the resultant waste of transport capacity, transit time increases, transportation costs, etc. more than the normal form of transport. Logistics enterprises in the logistics costs would be reduced, so that the logistics enhance the competitiveness of enterprises, which not only requires companies to reasonable arrangements logistics and transport, logistics and transport make to improve the quality and efficiency, but also good at making use of modern science and technology, in order to logistics and transport and logistics planning in the whole logistics system to be considered, taking into account various factors to the development of transport and logistics, the logistics is the third profit source of economic development in our truly reflected.
\end{abstract}

Keywords-Modern Logistics; Logistics and transport; Rationalization of transport; Measures

\section{INTRODUCTION}

The rationalization of transport contributes to make full use of the transportation ability, enhance the transportation efficiency, promote the rational division of transportation modes and apply the least social transportation labor force as well as promptly satisfy the transportation demand of the national economy. In this way, the transportation route of goods is the most reasonable, with the least intermediate links. It takes the least time and shortest distance to send the goods to the destination, quickening the velocity of goods. Because the goods can be rapidly put into the market, it saves costs for the department of goods and material, accelerates the speed of the fund flow and reduces losses of goods, therewith getting the good economic effect. Meanwhile, it reduces the waste in transportation and guarantees the transportation quality of goods. Hence, the ability of transportation is fully developed and the social labor consumption is lowered. Otherwise, the unreasonable transportation will waste the human, physical and financial resources which push the price of the product to become higher. The increase of the commodity value due to the operation of the logistics personnel results in the growth of the product price, which aggravates buyer's burden.

\section{INTRODUCTION OF MODERN LOGISTICS AND TRANSPORTATION MODES}

\section{A. Introduction of Modern Logistics}

\section{1) Concept of Modern Logistics}

Modern logistics is a process of conducting the effective flow and storage planning, implementation and control of raw material, interim stock, final products or the relevant information from the origin to the place for commodity consumption. Its objective is to promptly satisfy the needs of consumers.

\section{B. Introduction of Logistics and Transport}

\section{1) Concept of Transport}

Any logistics link cannot be without the transport which plays a very important role in the logistics. Transport refers to the movement of goods from one place to another. However, this movement mainly depends on the transport capacity. It is the activity of changing the spatial position of the object by taking advantage of a certain tool. During this process, there must be a series of operations including the concentration of goods, distribution, transportation and loading \& unloading. According to functions of the logistics system in different cases, transport can be classified into the logistics of production and logistics of sales. Although transport only changes the position of products without any change of products values, the place utility of products takes change.

\section{2) Transport Principles}

Transport principles are the basic rules in the transport management and operation. The so-called transport principles chiefly include the scale principle of transport, 
distance principle and speed principle. The scale principle is that the goods transport cost of each unit weight will gradually reduce with the increase of the freight volume. The distance principle indicates that the increase speed of the transportation cost will become slower if the distance of a transport gets longer. In other words, the cost per unit transportation distance gradually lessens. The freight cost of a transport is related to its distance. The relationship is shown in Fig. 1.

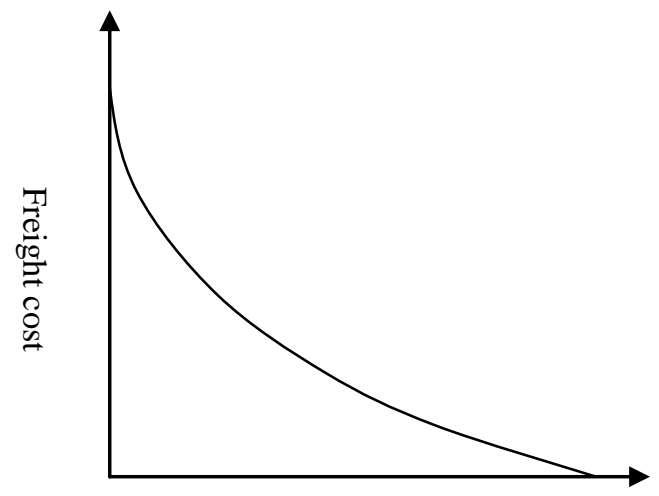

Distance

Figure 1. The relationship between the freight cost and distance

\section{Selection of Transportation Modes}

1) Comparison of Various Transportation Modes

There are five modes of modern logistics and transport. The comparison of costs of various transportation modes is analyzed in Table I.

Based on the above transportation modes, different comprehensive transportation can be set. All transportation modes have their own transport routes, transport tools, transport technologies, economical efficiencies and reasonable scope of application.

\section{2) Selection of Transportation Modes}

\section{a) Single transportation mode selection}

While choosing the transportation mode, it should take the service characteristics of transport tools as the standard of judgment. The factors that ought to be taken into account include the freight cost, transport time, transportation ability and security of goods.

\section{b) Multimodal Transportation Selection}

Multimodal transportation indicates that at least more than two transportation modes are utilized for providing the transport service. Five transportation modes can have different combinations. Yet the reasonable multimodal transportation mode combined is few. In the normal case, only the combination of railway and road as well as the combination of road or railway with waterway has quite good practicability.

The development of multimodal transportation is really good for the logistics carriers. It increases the alternatives for the logistics system design, thereby reducing the logistics cost and improving the service.

Wherever Times is specified, Times Roman or Times New Roman may be used. If neither is available on your word processor, please use the font closest in appearance to Times. Avoid using bit-mapped fonts if possible. TrueType 1 or Open Type fonts are preferred. Please embed symbol fonts, as well, for math, etc.

TABLE I. COMPARISON OF COSTS OF VARIOUS TRANSPORTATION
MODES

\begin{tabular}{|c|c|c|}
\hline $\begin{array}{c}\text { Transportation } \\
\text { Mode }\end{array}$ & Fixed Cost & Variable Cost \\
\hline Railway & $\begin{array}{l}\text { High (rail and } \\
\text { vehicle) }\end{array}$ & Low \\
\hline Road & $\begin{array}{l}\text { High (road } \\
\text { works and } \\
\text { vehicle) } \\
\end{array}$ & $\begin{array}{l}\text { Moderate (fuel } \\
\text { and } \\
\text { maintenance) }\end{array}$ \\
\hline Waterway & $\begin{array}{c}\text { Moderate } \\
\text { (vessel and fixed } \\
\text { equipment) }\end{array}$ & Low \\
\hline Aviation & $\begin{array}{l}\text { Low (cargo } \\
\text { aircraft and } \\
\text { airport) } \\
\end{array}$ & $\begin{array}{l}\text { High (fuel and } \\
\text { maintenance) }\end{array}$ \\
\hline Pipeline & $\begin{array}{l}\text { Highest (pipe } \\
\text { laying) }\end{array}$ & Lowest \\
\hline $\begin{array}{c}\text { Transportation } \\
\text { Mode }\end{array}$ & Fixed Cost & Variable Cost \\
\hline Railway & $\begin{array}{l}\text { High (rail and } \\
\text { vehicle) }\end{array}$ & Low \\
\hline Road & $\begin{array}{l}\text { High (road } \\
\text { works and } \\
\text { vehicle) }\end{array}$ & $\begin{array}{c}\text { Moderate (fuel } \\
\text { and } \\
\text { maintenance) }\end{array}$ \\
\hline Waterway & $\begin{array}{c}\text { Moderate } \\
\text { (vessel and fixed } \\
\text { equipment) }\end{array}$ & Low \\
\hline Aviation & $\begin{array}{l}\text { Low (cargo } \\
\text { aircraft and } \\
\text { airport) }\end{array}$ & $\begin{array}{l}\text { High (fuel and } \\
\text { maintenance) }\end{array}$ \\
\hline Pipeline & $\begin{array}{l}\text { Highest (pipe } \\
\text { laying) }\end{array}$ & Lowest \\
\hline
\end{tabular}

\section{PERFORMANCE OF UNREASONABLE TRANSPORTATION AND INFLUENCE FACTORS OF RATIONALIZATION OF TRANSPORT}

\section{A. Performance of Unreasonable Transportation and Analysis}

The unreasonable cargo transportation causes the increase of time and links in the transportation process, the slow flow, the huge losses, the higher cost and waste of transport capacity and social labor, having influence on the production and market supply. The unreasonable transportation can mainly be classified into the following types.

a) Unreasonable Transportation Relative to the Transportation Direction

Empty departure and deadhead. Empty or driving without cargo is the most unreasonable transportation mode.

The counter-flow transportation sometimes is called the opposite direction transportation or cross-haul traffic. 
All goods of the same kind or goods which can be replaced by each other yet don't affect the management, technology and benefits are sent to the relative directions in the same line or two parallel lines but cross or overlap with some or the whole haul of the other part, which is called counterflow transportation.

2) Unreasonable Transportation Relative to the Transportation Distance

\section{a) Round about Transportation}

The round about transportation is a kind of unreasonable transportation phenomenon that the goods detour. It should have chosen the shorter distance to deliver goods. However, it finally selects an unreasonable way with long transportation distance. The round about transportation is quite complicated. It cannot be simply handled. Sometimes, due to the poor planning and unfamiliar geography as well as the unreasonable arrangement, the detour occurs. Such detour is considered as unreasonable transportation.

\section{b) Unduly Long Haul Traffic}

The unduly long haul traffic is one of unreasonable transportations that the goods and material are transported from the far place rather than the close one. That is, the goods of the same quality needed could have been taken from the supplying place closer to the sales place. Yet, the goods are taken from quite far place, beyond the reasonable flow range of the goods. Consequently, it doesn't adopt the short-distance transportation, elongating the freight haul distance.

3) Unreasonable Transportation Relative to the Traffic Volume

\section{a) Repeated Transportation}

The repeated transportation is an unreasonable transportation mode that a kind of goods could have directly reached the destination but unloads in the midway and repeatedly load due to some reasons.

\section{b) Ineffective Traffic}

It refers to the transportation of loading goods that include a large number of impurities contents or the content of impurities beyond a certain standard.

4) Unreasonable Transportation Relative to the Improper Selection of Transport Capacity

Here, it is a kind of unreasonable transportation that doesn't apply the proper transportation according to the advantages of various vehicles. It has the following types.

a) Selection of Overland Service Rather than Waterway

While the goods can be transported both by sea and land, it chooses the railway transportation or road transportation rather than the waterway or combination of water-land transport with quite low cost. Due to their high costs, the advantages of the water transportation are never utilized.

b) Railway and Large Vessel Transportation for a Close Distance

There is no economic operation mileage of railway and large vessel. However, they are applied for transportation, which causes the unreasonable transportation.

c) Improper Carrying Capacity of Means of Transport.
For the selection of vehicles, the decision is made blindly, never depending on the quantity and weight of the cargo. It causes the excessive overload, disabled vehicle and not-full loading of vehicle as well as waste of transportation capacity.

5) Unreasonable Transportation Relative to Improper Consignment Mode

Consigning for shipment is a kind of basic way of logistics. For the owner of goods, he has the choice for the better shipment way but doesn't apply, resulting in the increase of the transportation cost and unreasonable utilization of the transportation capacity. In transportation, it can choose the truckload but take the LCL consignment. It can use the through transportation but select the transfer transport. While it should apply the transfer transport, it chooses the through transportation. All above phenomenon belong to the unreasonable transportation caused by the improper consignment.

\section{MEASURES AND SUGGESTION OF RATIONALIZATION OF TRANSPORT}

\section{A. Measures of Rationalization of Transport}

Various unreasonable transportation modes are chosen under some specific conditions. While making the judgment, we must pay attention to the prerequisite. Otherwise, it is possible to generate the errors in judgment. Thus, we should take the consideration by putting the logistics system into the big environment.

1) Balance Transportation of Production and Marketing of Zone.

For the reasonable transportation of the cargo, the method of balance transportation of production and marketing of zone is to make the production of a zone fixed at the consumption of a zone when the logistics transportation is arranged. According to the logistics and transportation condition as well as the production and marketing distribution, under the basic condition of the production and marketing balance of cargo, it makes the transportation route shortest based on the principle of production and marketing at a close distance.

2) Try to apply the through transportation.

In the process of pursuing the rationalization of transport, the through transportation is one of significant transportation modes. The key of its pursuit on the rationalization is to enhance the transport speed, save the loading and unloading cost as well as reduce the losses of trans-shipment cargo through decreasing the overload and transfer loading. The advantage of the through transportation can be obviously seen in the batch transportation or full vehicle of users' demand at a time.

3) "Four" Direct Transports.

"Four" Direct Transports refers to the direct transport from the factory, direct transport from the wharf or station, direct transport from the warehouse and overload by bus or ship. It is a kind of transportation mode contributing to cut down the link of the trans-shipment transportation and try to accomplish the task with the least transfer times.

4) LCL Transportation.

This mode sometimes is called "LCL transit subcarriage". It is that the consigner sends different products 
to the same station and the LCL of the same consignee is assigned in the same railway wagon by the logistics and transport enterprises to be sent to the destination in the way of the truckload while the railway transportation is used for delivering the cargo. Or, LCL sent to different stations of the same direction is assigned to put in one railway wagon and delivered to a proper station. And then, they are transferred for sub-carriage. What it mainly transports is the sundry goods.

\section{5) Stowage Transportation}

The stowage transportation chiefly makes full use of the volume and weight of the vehicle to reasonably arrange the loading cargo so as to achieve the rationalization of transportation. The stowage transportation usually focuses on the reasonable stowage of the light and heavy commodity. In the case of transportation of heavy cargo, it can be also allocated with some light cargo. For example, while the heavy cargo is transported, the wood and moso bamboo can be also transported together. Under the situation that the transportation capacity doesn't change, it can achieve quite significant effect.

\section{B. Suggestion of Rationalization of Transport}

1) Change the idea and set up the view of modern logistics.

Because Chinese logistics and transportation industry is affected by the traditional planned economic system, the management and operation of the logistics transportation have been in a distributed state for a long time. Such management and operation cannot meet the development demand of the modern society any more. Therefore, to well develop the logistics and transportation industry, we firstly change our ideas and set up the view of the market economic system.

2) Strengthen the construction of logistic science and talent cultivation.

China is lack of the professional talents in the logistics and transportation industry, which restricts the development of the logistics and transportation. Hence, if it intends to be successful in the competitive market, it should attach importance to the cultivation of talents. It should establish more comprehensive talent cultivation mechanism and improve the talent quality and professional knowledge.

3) Create the good environment for development and perfect the infrastructure.

The development of each industry is based on the infrastructure. The progress of the logistics and transportation industry depends on perfect infrastructure. In reality, the infrastructure of the logistics and transportation industry is not sound, which seriously blocks the development of the logistics and transportation.

4) Quicken the information circulation efficiency and promote the logistics information to higher level.

Now, China has stepped into the network times. The logistics and transportation industry also keeps pace with the network, to seek for its service mode in the information, found the service station of the logistics and transportation information and speed up the logistics informationization process. Especially, it applies the advanced professional logistics devices and technologies to each link of the logistics and transportation so as to enhance the work efficiency and reduce the service cost.

6) Establishment of strategic alliance in the inner enterprise to stand out the overall advantages of the supply chain and fully develop the social transport system.

The logistics companies in China generally have the small scale. There is few large-scale logistics company. Faced with the situation of mixing of large and small logistics companies, it is hard to take the scientific overall operation.

\section{CONCLUSION}

Which method should be taken for reducing the logistics cost? Which method can effectively improve the service quality of logistics enterprises? For these issues, they not only require us to reasonably arrange the logistics transportation, but also ask us to have the experience of the practical logistics operation. The quality and benefit of logistics and transportation depend on the development of modern science and technology. We should treat the logistics and transportation and arrange the work from the systematical and overall perspective. Only in this way can the logistics and transportation industry be better developed and the logistics really be the third profit resource of the enterprise.

Modern logistics is developing towards the informationization. We should be good at taking advantage of the science and technology to quicken the speed of the informationization of logistics and transportation industry. Various sciences and technologies should be used to push the advancement of the logistics and transportation towards the intelligence and greenization. Besides, we should arrange the reasonable logistics and transportation optimize the unreasonable transportation, save the transport resource and reduce the waste of the transport capacity.

\section{REFERENCES}

[1] Li Zhang, Xuesong Li. Modern Logistics and Transportation Management. Beijing: Chinese Waterpower Press, 2007, pp.36-66.

[2] Jianhua Meng. Modern Logistics Management. Beijing: Tsinghua University Press, 2004, pp.113-118.

[3] Wen Du. Logistics, Transportation and Distribution Management. Beijing: China Machine Press, 2006, pp.105-110.

[4] Qiang Zhu, Zigang Yan. Practice of Transport Management. Beijing: China Logistics Press, 2006.

[5] Xuesong Hu. Research of Rationalization of Logistics and Transport. China Business, 2010.

[6] Hongli Huang. Factors Influencing the Rationalization of Logistics and Measures. Logistics Engineering and Management, 2012, pp.32-33.

[7] Weibin Liu, Jianyang Liu. Effective Measures of Rationalization of Transport. Heilongjiang Communications Science and Technology, 2004, (11), pp.60-63.

[8] Jin Zhang. Logistics System Planning. Beijing: China Railway Publishing House, 2004, pp. 47-68.

[9] Jean-Michel Thizy. Illustrating Constraint Programming Systems in Logistic Planning, 2006. 